\title{
Virally induced mortality of Phaeocystis globosa during two spring blooms in temperate coastal waters
}

\author{
Anne-Claire Baudoux, Anna A. M. Noordeloos, Marcel J. W. Veldhuis, \\ Corina P. D. Brussaard*
}

Department of Biological Oceanography, Royal Netherlands Institute for Sea Research, PO Box 59, 1790 AB Den Burg, The Netherlands

\begin{abstract}
This study reports virally mediated mortality rates of Phaeocystis globosa single cells in the southern North Sea during 2 consecutive spring blooms (2003 and 2004). An adapted dilution method was used to estimate viral lysis and microzooplankton grazing simultaneously. Parallel dilution experiments were performed with $30 \mathrm{kDa}$ ultrafiltrate (virus and grazer-free diluent) and $0.2 \mu \mathrm{m}$ filtered seawater (grazer-free, but virus-containing diluent). Specific viral lysis rates were calculated from the difference in P. globosa growth rates between the 2 dilution series after $24 \mathrm{~h}$ incubation under natural conditions. The validity of this method was tested using a culture of $P$. globosa infected with a known P. globosa virus (PgV). The field data show that virally induced mortality can be a substantial loss factor for $P$. globosa single cells (up to $0.35 \mathrm{~d}^{-1}$ ), comparable to that due to microzooplankton grazing (up to $0.4 \mathrm{~d}^{-1}$ ). Viral lysis was the major cause of total P. globosa cell lysis. Assuming no loss due to sinking, viral lysis accounted for 5 to $66 \%$ of the total mortality of $P$. globosa single cells. Viral lysis and total putative PgV abundance increased concomitantly with abundance of $P$. globosa single cells whilst the increase in infective PgV was delayed. This delay may be caused by the formation of transparent exopolymeric particles that are generated when P. globosa colonies disrupt and are known to passively adsorb viruses. Viruses and microzooplankton were shown to be major controlling agents of $P$. globosa single cells, although their relative significance varied over the course of the bloom and between years.
\end{abstract}

KEY WORDS: Algae - Virally induced mortality $\cdot$ Cell lysis $\cdot$ Dilution assay $\cdot$ Microzooplankton grazing $\cdot$ Phaeocystis globosa $\cdot$ North Sea

\section{INTRODUCTION}

With phytoplankton forming the basis of the pelagic marine food web, their dynamics critically influence the functioning of marine ecosystems. Traditionally, grazing and sinking are considered important causes of phytoplankton mortality but over the last decade, cell lysis has also been recognized as a significant loss factor for phytoplankton (Van Boekel et al. 1992, Brussaard et al. 1995, Agusti et al. 1998). Viral infection is a major cause of phytoplankton cell lysis, which affects population dynamics and diversity (for review see Brussaard 2004b). Successful infection depends on the encounter between the virus and the host, which is directly affected by their abundance. During algal bloom events, which are defined by high cell abundance, virally induced mortality has indeed been reported to be a substantial loss factor (Bratbak et al. 1993, Brussaard et al. 1996b, Tomaru et al. 2004).

Phaeocystis globosa (Prymnesiophyte) is a bloomforming phytoplankter with a world-wide distribution. This marine microphytoplankter is well known for its complex polymorphic life cycle, including flagellated cells $(5-7 \mu \mathrm{m}$ diameter) and colonies (up to $1-2 \mathrm{~cm}$ ), which consist of colonial cells embedded in a polysaccharide (mucus) matrix. Typically, in the southern 
North Sea, $P$. globosa develops into high biomass spring blooms, which contribute the bulk of the local primary production (Lancelot \& Billen 1984). These blooms also affect microbial food web dynamics and biogeochemical processes (Stefels \& Van Boekel 1993, Brussaard et al. 1995, 1996a, 2005b).

Viruses infecting Phaeocystis globosa (PgVs) have been isolated and characterized (Brussaard et al. 2004, Baudoux \& Brussaard 2005). A recent mesocosm experiment demonstrated that virally mediated mortality of P. globosa accounted for 30 to $100 \%$ of the total lysis of $P$. globosa single cells. In contrast, cells embedded in a colonial matrix tend to escape viral infection (Brussaard et al. 2005a, Ruardij et al. 2005). To our knowledge, estimates of virally mediated mortality under natural P. globosa bloom conditions do not exist. The dynamics of viral abundance, the virus to $P$. globosa ratio and total cell lysis rates of $P$. globosa during bloom events, however, suggest that viruses are an important source of mortality for this alga (Brussaard et al. 2004, 2005a).

Direct methods for estimating viral lysis of phytoplankton are rare, and, to date, most viral lysis rates recorded in the literature rely on theoretical calculations or are based on indirect measurements (for review see Brussaard 2004b). Recently, an adaptation of the classical dilution approach (Landry \& Hassett 1982) provided estimates of the viral lysis of the picophytoplankter Micromonas pusilla in mesocosms (Evans et al. 2003). The current study has applied this method to Phaeocystis globosa under natural conditions. Our work aimed at elucidating the relative significance of viral lysis compared to microzooplankton grazing and total cell lysis of $P$. globosa single cells during 2 consecutive spring blooms.

\section{MATERIALS AND METHODS}

Study site and sampling. Sampling of the coastal southern North Sea was performed twice a week between March (Day 60) and June (Day 180) in 2003 and 2004 from the jetty of the Royal Netherlands Institute for Sea Research (NIOZ). Because the jetty is located at the outer border of a major tidal inlet, samples were collected on the incoming high tide. Samples containing freshwater run-off (salinity <27\%) were not taken into account (1 out of 46 samples).

Chemical parameters. Nutrient samples (ca. $5 \mathrm{ml}$ ) were gently filtered through $0.2 \mu \mathrm{m}$ pore-size polysulfone filters (Acrodisc, Gelman Sciences) and stored at $-50^{\circ} \mathrm{C}$ (or $4^{\circ} \mathrm{C}$ for the reactive silicate) until analysis. Analyses were performed using a TrAAcs 800 autoanalyzer for dissolved orthophosphate (Murphy \& Riley 1962), nitrogen (nitrate, nitrite and ammonium;
Helder \& De Vries 1979, Grasshoff 1983), and reactive silicate (Strickland \& Parsons 1968). The limit of detection was $0.03 \mu \mathrm{M}$ for phosphate, $0.1 \mu \mathrm{M}$ for ammonium, $0.01 \mu \mathrm{M}$ for nitrite, $0.15 \mu \mathrm{M}$ for nitrate, and $0.05 \mu \mathrm{M}$ for silicate.

The concentration of transparent exopolymeric particles (TEP) in $\mu \mathrm{g}$ equiv. gum xanthan (equiv. GX) $\mathrm{l}^{-1}$ was measured according to Passow \& Alldredge (1995). Replicate samples (30 to $75 \mathrm{ml}$ ) were filtered through $0.4 \mu \mathrm{m}$ pore-size polycarbonate filters (Poretics). The particles retained on the filter were stained with $500 \mu$ l of a $0.02 \%$ solution of Alcian blue prepared in $0.06 \%$ acetic acid $(\mathrm{pH} 2.5)$. After staining $(<2 \mathrm{~s})$, the filters were rinsed 3 times with Milli-Q (Millipore) to remove excess dye. The filters were immediately transferred into $20 \mathrm{ml}$ glass tubes and soaked for $3 \mathrm{~h}$ in a solution of $80 \% \mathrm{H}_{2} \mathrm{SO}_{4}$ with gentle agitation every $30 \mathrm{~min}$. The samples were analyzed spectrophotometrically at $727 \mathrm{~nm}$ (U-3010 Hitachi).

Microbial abundances. Samples collected for phytoplankton pigments (150 to $700 \mathrm{ml}$ ) were filtered through GF/F glass fiber filters (Whatman) and stored at $-50^{\circ} \mathrm{C}$. The extract from the filters was analyzed by high pressure liquid chromatography (HPLC) after extraction in $4 \mathrm{ml}$ of $100 \%$ methanol buffered with $0.5 \mathrm{~mol} \mathrm{l}^{-1} \mathrm{am}-$ monium acetate and homogenized for $15 \mathrm{~s}$. The relative abundance of the taxonomic group Prymnesiophyceae (specifically Phaeocystis globosa during our study) was determined using CHEMTAX (Mackey et al. 1996, Riegman \& Kraay 2001).

Phaeocystis globosa single cells were enumerated in $50 \mu \mathrm{m}$-sieved and unfixed samples using a Beckman Coulter XL-MCL flow cytometer equipped with a $488 \mathrm{~nm}$ air-cooled laser. Special care was taken to avoid rupture of $P$. globosa colonies during sieving using a small volume of sample. Fixation of the sample resulted in the disintegration of the colonial matrix; therefore the total abundance of P. globosa cells (including both single and colonial cells) could be obtained from unfiltered samples that were fixed to a $1 \%$ final concentration with formaldehyde:hexamine solution (18\% v/v:10\% w/v). These fixed samples were frozen in liquid nitrogen and stored at $-80^{\circ} \mathrm{C}$ until flow cytometry analysis. Fixation and freezing did not affect the P. globosa cell counts. P. globosa cells were discriminated on the basis of their natural red chlorophyll autofluorescence and forward scatter signal.

The abundance of virus-like particles resembling $\mathrm{PgV}$ was determined on glutaraldehyde fixed samples (final concentration $0.5 \%$ glutaraldehyde, frozen in liquid nitrogen and stored at $-80^{\circ} \mathrm{C}$ prior analysis) using a Beckton-Dickinson FACSCalibur flow cytometer, with a $15 \mathrm{~mW} 488 \mathrm{~nm}$ air-cooled argon-ion laser according to Brussaard (2004a). Thawed samples were diluted (dilution factor $>25$ ) in $0.2 \mu \mathrm{m}$ filtered sterile 
TE-buffer ( $\mathrm{pH}$ 8) and stained with the nucleic acidspecific dye SYBR Green I at a final concentration of $0.5 \times 10^{-4}$ of the commercial stock (Molecular Probes). Putative PgV could be discriminated on the basis of the green fluorescence and side scatter signature (Fig. 1), which was identical to that of $\mathrm{PgV}$ isolates from the same geographical location, and kept in culture at the Royal NIOZ (Brussaard et al. 2004).

The abundance of infectious PgV was estimated using the end-point dilution approach (most probable number, MPN; Suttle 1993). Natural seawater was filtered through a $1 \mu \mathrm{m}$ polycarbonate filter (Poretics) and serial diluted (8 titers, 5 replicates) with exponentially growing Phaeocystis globosa Pg-G (RUG culture collection) and Pg-01MD06 (NIOZ culture collection). To screen for rare PgV in 2004, an additional natural sample was filtered through a $1 \mu \mathrm{m}$ polycarbonate filter (Poretics), concentrated ca. 40 times using a VivaFlow 200 ultrafiltration system (Vivascience), and added to a $P$. globosa host culture $(20 \% \mathrm{v} / \mathrm{v})$. Both $P$. globosa strains originated from the North Sea and were chosen for their different sensitivity to $\mathrm{PgV}$, which was relatively broad for Pg-G and specific for Pg-01MD06 (Baudoux \& Brussaard 2005). The algae were grown in a 1:1 mixture of $f / 2$ medium (Guillard 1975) and enriched artificial seawater (ESAW) (Harrison et al. 1980, Cottrell \& Suttle 1991), completed with Tris- $\mathrm{HCl}$ and $\mathrm{Na}_{2} \mathrm{SeO}_{3}$ (Cottrell \& Suttle 1991). The dilution series were incubated for $10 \mathrm{~d}$ at $15^{\circ} \mathrm{C}$ under a light:dark cycle of 16:8 h at $100 \mu \mathrm{mol}$ quanta $\mathrm{m}^{-2} \mathrm{~s}^{-1}$. Algal growth was monitored via in vivo chlorophyll fluorescence using a Turner Designs fluorometer

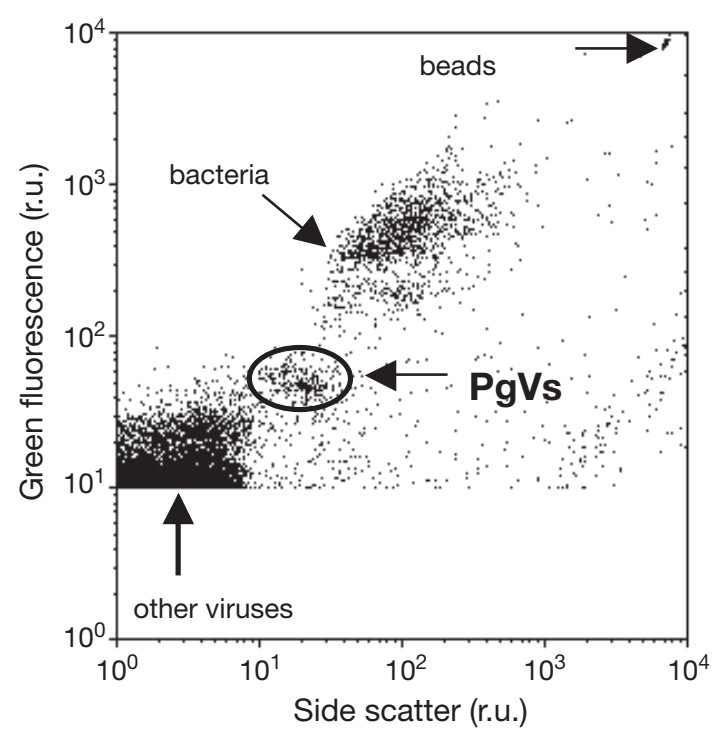

Fig. 1. Flow cytometry signature of viruses infecting Phaeocystis globosa (PgVs) from natural seawater. PgVs were detected by their green fluorescence and side scatter upon staining with SYBR Green I. r.u.: relative units and compared to noninfected controls. Those dilutions that showed signs of cell lysis were scored positive when $\mathrm{PgV}$ proliferation could be confirmed (using flow cytometry as described above). The positive scores were converted to abundance of infective PgV using an MPN assay computer program (Hurley \& Roscoe 1983).

Loss parameters of Phaeocystis globosa. Total cell lysis rates of $P$. globosa $\left(\mathrm{d}^{-1}\right)$ were estimated using the dissolved esterase activity (DEA) assay described in Brussaard et al. (1996a) and adapted by Riegman et al. (2002). Particulate esterase activity (PEA) was obtained by subtracting the DEA $(0.2 \mu \mathrm{m}$ pore-size filter) from the total esterase activity (unfiltered natural sample). The DEA was corrected for non-enzymatic hydrolysis of the substrate, as measured in natural samples filtered through $10 \mathrm{kDa}$ (PES Vivaspin, Vivasciences), and for a decay of esterase activity in seawater using a half-life time of $48 \mathrm{~h}$ (Riegman et al. 2002). The P. globosa-specific PEA was calculated by multiplying the total PEA by the contribution of P. globosa to total chlorophyll-based CHEMTAX pigment analysis described in an earlier subsection (Brussaard et al. 2004). Data points were occasionally omitted when an unrealistically high lysis rate was obtained from the ratio of low produced DEA to low $P$. globosa-specific PEA. This may occur at the onset of the bloom when $P$. globosa biomass is still low.

Virally induced mortality of Phaeocystis globosa single cells was estimated using the viral lysis dilution assay according to Evans et al. (2003). Parallel dilution series of natural seawater was performed with $0.2 \mu \mathrm{m}$ filtered natural sample (Poretics, Millipore) to obtain microzooplankton grazing rate (Landry \& Hassett 1982), and with a $30 \mathrm{kDa}$ filtered natural sample (polyether sulfone membrane, Pellicon filtration system, Millipore) to obtain grazing and viral lysis rates. Viral lysis rates were determined from the difference between the 2 dilution series.

The viral lysis dilution assay has only been applied to Micromonas pusilla (Evans et al. 2003); therefore we checked the validity of this method for Phaeocystis globosa. The test experiment was conducted using an exponentially growing $P$. globosa Pg-G $\left(1 \times 10^{5}\right.$ cells $\mathrm{ml}^{-1}$ ) in combination with the lytic virus PgV-07T (Brussaard et al. 2004) at a multiplicity of infection (MOI) of 10, as determined by the MPN assay (see preceding subsection). In order to simplify the interpretation of the test results no grazers were added; therefore, identical net growth rates were recorded for all dilutions with the $0.2 \mu \mathrm{m}$ pore-size water, and thus the estimated grazing rate was not significantly different from zero $\left(0.02 \pm 0.07 \mathrm{~d}^{-1}\right.$, Fig. 2A). The dilution series with the $<30 \mathrm{kDa}$ diluent yielded a regression slope of $1.3 \pm 0.07 \mathrm{~d}^{-1}$, which corresponds to the viral lysis rate 


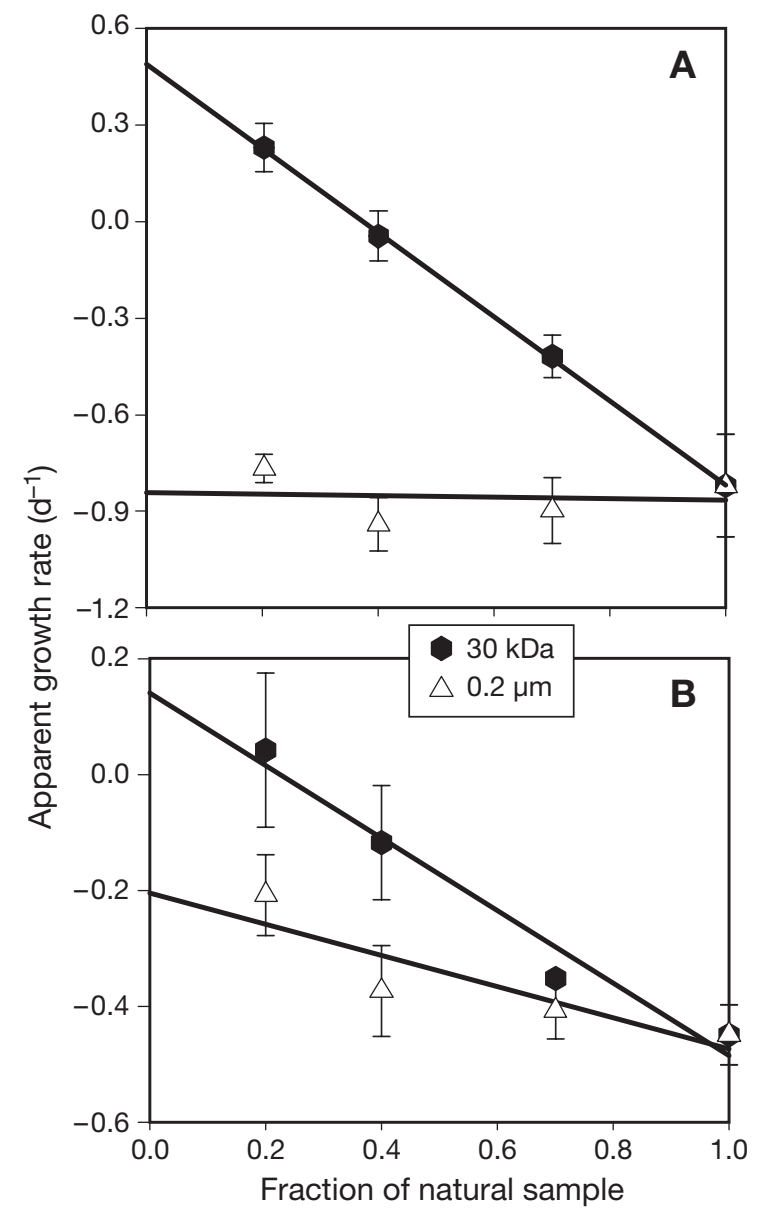

Fig. 2. Phaeocystis globosa (Pg-G). Apparent growth rate vs. fraction of natural sample for (A) test experiment using host-virus model system Pg-G-PgV-07T (no grazers added) and (B) typical field sample (Day 132, 2003). Parallel dilution experiments were performed in $0.2 \mu \mathrm{m}$ filtered seawater (grazer-free, but virus-containing diluent) and $30 \mathrm{kDa}$ ultrafiltrate (virus and grazer-free diluent). Regression coefficient of apparent growth rate vs. dilution factors resulting from $0.2 \mu \mathrm{m}$ dilution series represents microzooplankton grazing rate, and from $30 \mathrm{kDa}$ series represents microzooplankton grazing plus viral lysis. Viral lysis rates $\left(\mathrm{d}^{-1}\right)$ were estimated from difference in regression coefficient of the 2 sets of dilutions. For legibility we have averaged the triplicate apparent growth for each dilution level; this does not affect estimated mortality rates

in this test since there was no grazing. Knowing that $P$. globosa undergoes lysis 14 to $16 \mathrm{~h}$ after infection (Baudoux \& Brussaard 2005), we conclude that the lysis rate obtained during the $24 \mathrm{~h}$ incubation originated from 1 lytic cycle. An independent 1-step lytic growth cycle experiment using the same strain of $P$. globosa and $\mathrm{PgV}$ validated the results of the dilution assay. The viral lysis rate $\left(1.4 \mathrm{~d}^{-1}\right)$ calculated from this growth experiment was comparable to that obtained with the laboratory viral lysis dilution assay $\left(1.3 \mathrm{~d}^{-1}\right)$. These tests demonstrated the utility and validity of the viral lysis dilution assay, allowing this method to be applied in the field to P. globosa (Fig. 2B).

The experimental design of the dilution assay for field samples is shown in Fig. 3. All materials (carboys, tubing, bottles) used for this assay were cleaned for $24 \mathrm{~h}$ with $0.1 \mathrm{~N} \mathrm{HCl}$, after which they were rinsed 3 times with Milli-Q and once with the sample. To prevent losses of virus, grazers or disruption of Phaeocystis globosa colonies, sieving and filtration were performed with special care by siphoning and avoiding air bubbling. Polycarbonate Poretics filters (47 mm, Millipore) were exclusively used and replaced frequently during the filtration to avoid loss of viral infectivity and abundance (Suttle et al. 1991). Samples were processed under dimmed light (to prevent light stress) and in situ temperature $\left(4\right.$ to $\left.18^{\circ} \mathrm{C}\right)$. The seawater used for the dilution (10 l) was collected and processed ca. $2 \mathrm{~h}$ before high tide in order to minimize the handling time of the natural water to be diluted. The 101 sample was pretreated by reverse sieving through 200 and $50 \mu \mathrm{m}$ mesh (20 cm diameter) to remove larger grazers and P. globosa colonies. Subsequently, the sample was filtered through 3 and $0.2 \mu \mathrm{m}$ pore-size filters. A $5 \mathrm{l}$ aliquot of the $0.2 \mu \mathrm{m}$ filtrate was used for generating the $0.2 \mu \mathrm{m}$ dilution series. The remaining 51 were ultrafiltrated through $30 \mathrm{kDa}$ and used as diluent for the $30 \mathrm{kDa}$ dilution series.

At high tide, 201 of natural seawater were collected de novo. The salinity of the 2 batches of seawater used for the experiment was measured and comparable in all cases (difference $<0.5 \%$ ). The sample was reverse sieved through $200 \mu \mathrm{m}$ mesh to remove mesozooplankton, and immediately used to set up 4 levels of dilution $(20,40,70$ and $100 \%$ sample) in 21 polycarbonate bottles that already contained the $0.2 \mu \mathrm{m}$ or the $30 \mathrm{kDa}$ diluents. From the 21 dilution bottle, 3 incubation bottles ( $250 \mathrm{ml}$ polycarbonate bottles) were carefully filled by siphoning and $5 \mathrm{ml}$ subsample were taken (time, $t=0 \mathrm{~h}$ ). These incubation bottles were refilled to the top with the original dilution waters (remaining from the 21 bottles) in order to avoid any air bubbles being trapped inside upon closure. All bottles were incubated at near-surface depth (ca. 1 to $2 \mathrm{~m}$ ) under natural light and temperature conditions in a basket in the NIOZ harbor (protected from wavemotion). Another sample of $5 \mathrm{ml}$ was taken after a $24 \mathrm{~h}$ incubation period.

The set-up of the laboratory assay was similar to the field assay with the exception that a Phaeocystis globosa culture free of virus and grazers was used. Viruses infecting P. globosa (0.2 $\mu \mathrm{m}$ filtered PgV-07T lysate, Poretics filters, Millipore) were added (MOI = 10 ) to the diluent directly after the $0.2 \mu \mathrm{m}$ filtration step and to the P. globosa culture just prior to dilution. The $P$. globosa culture that had to be diluted was infected 
1 PREPARATION DILUENTS

PREPARATION SAMPLES 2

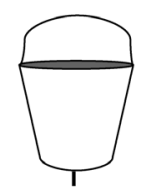

Natural sample

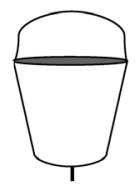

Reverse sieving $200 \mu \mathrm{m}$

$\downarrow$

Sieving $50 \mu \mathrm{m}$

$\downarrow$

$3 \mu \mathrm{m}$ filtration

$\prod$

$0.2 \mu \mathrm{m}$ filtration

$\prod$

$\mathrm{kDa}$ ultrafiltration

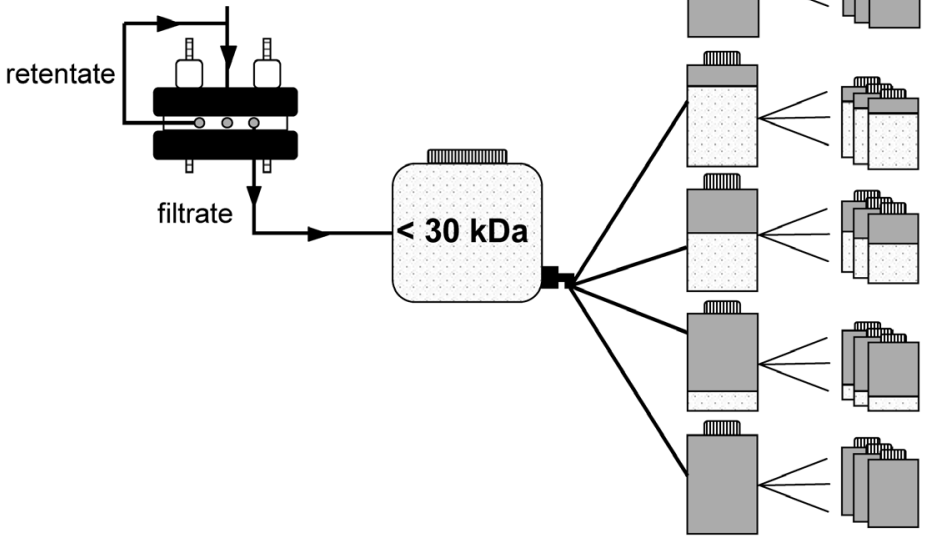

Reverse sieving $200 \mu \mathrm{m}$

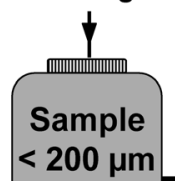

Fig. 3. Experimental design of viral lysis dilution assay (field assay). In Step 1, diluents were prepared ca. $2 \mathrm{~h}$ prior to Step 2, which entailed dilution with natural sample collected de novo at high tide. Samples were processed under dim light and at in situ temperature. Sample transfers were performed by siphoning or gentle pumping, avoiding damage to the organisms

just before setting up the dilutions in the 21 bottles. All bottles were incubated under the same growth conditions as the host culture $\left(15^{\circ} \mathrm{C}\right.$, light:dark cycle of 16:8 $\mathrm{h}, 100 \mu \mathrm{mol}$ quanta $\mathrm{m}^{-2} \mathrm{~s}^{-1}$ ).

For both field and laboratory assays, Phaeocystis globosa single cells were enumerated directly upon sampling after gentle sieving through $50 \mu \mathrm{m}$ mesh-size using a Beckman Coulter XL-MCL flow cytometer (3 replicates of each sample). The apparent growth

$20 \%$

$40 \%$

$70 \%$

$100 \%$

$20 \%$

$40 \%$

$70 \%$

$100 \%$

rate $\left(\mu, \mathrm{d}^{-1}\right)$ of $P$. globosa single cells was calculated for each sample from the changes in abundance during the incubation according to the equation:

$$
\mu=\ln N_{t_{24}}-\ln N_{t_{0}}
$$

where $N_{t_{0}}$ and $N_{t_{24}}$ are the abundance of $P$. globosa single cells at $t=0$ and $24 \mathrm{~h}$, respectively. A typical field example is presented in Fig. 2B. The regression coefficient of apparent growth rate vs. dilution factors for the $0.2 \mu \mathrm{m}$ dilution series represents the microzooplankton grazing rate $\left(M_{\mathrm{g}}\right)$, whereas the regression coefficient resulting from the $30 \mathrm{kDa}$ series represents both microzooplankton grazing and viral lysis $\left(M_{(\mathrm{g}+\mathrm{v})}\right)$. Subsequently, mortality rate due to viral lysis $\left(M_{\mathrm{v}}\right)$ was calculated as $M_{\mathrm{v}}=$ $M_{(\mathrm{g}+\mathrm{v})}-M_{\mathrm{g}}$.

$M_{\mathrm{g}}, M_{(\mathrm{g}+\mathrm{v})}$ and their respective standard errors $\left(\mathrm{SE}_{\mathrm{g}}\right.$ and $\left.\mathrm{SE}_{(\mathrm{g}+\mathrm{v})}\right)$ were calculated using Sigma plot software. The standard error of $M_{\mathrm{v}}$ was calculated as the squared root of the sum of squared $\mathrm{SE}_{\mathrm{g}}$ and $\mathrm{SE}_{(\mathrm{g}+\mathrm{v})}$.

\section{RESULTS}

\section{Chemical parameters}

For the 2 consecutive years of study a comparable pattern in nutrient dynamics was recorded from Days 60 to 180 (Fig. 4). Nitrate concentration declined steadily from 60 to $80 \mu \mathrm{M}$ on Day 60 to $0.3 \mu \mathrm{M}$ on Day 107 in 2003 and $0.8 \mu \mathrm{M}$ on Day 173 in 2004. For 2003, the nitrate concentration remained low until Day 119, after which it increased again slightly. In contrast, growth-limiting nitrate concentrations were not found during the sampling period in 2004. Inorganic phosphate concentrations declined sharply in both years, from 0.8 to $1 \mu \mathrm{M}$ on Day 60 to around $0.4 \mu \mathrm{M}$ from Days 90 to 95 . The concentration of phosphate in 2003 did not increase until Day 112. In 2004 it increased again quickly (Day 99), but a second decline was detected from Days 117 to $125(<0.1 \mu \mathrm{M})$. In both years, ammonium concentrations ranged between 0.5 and $5.8 \mu \mathrm{M}$ until Day 120, after which they increased substantially to maximum values of 9 and $16 \mu \mathrm{M}$ in 2003 and 2004, respectively. Silicate concentrations decreased steadily from the beginning of the sampling period until Day 83 in 2003 and Day 92 in 2004, after which the concentration stayed low (0.4 to $6 \mu \mathrm{M})$ in both years. 

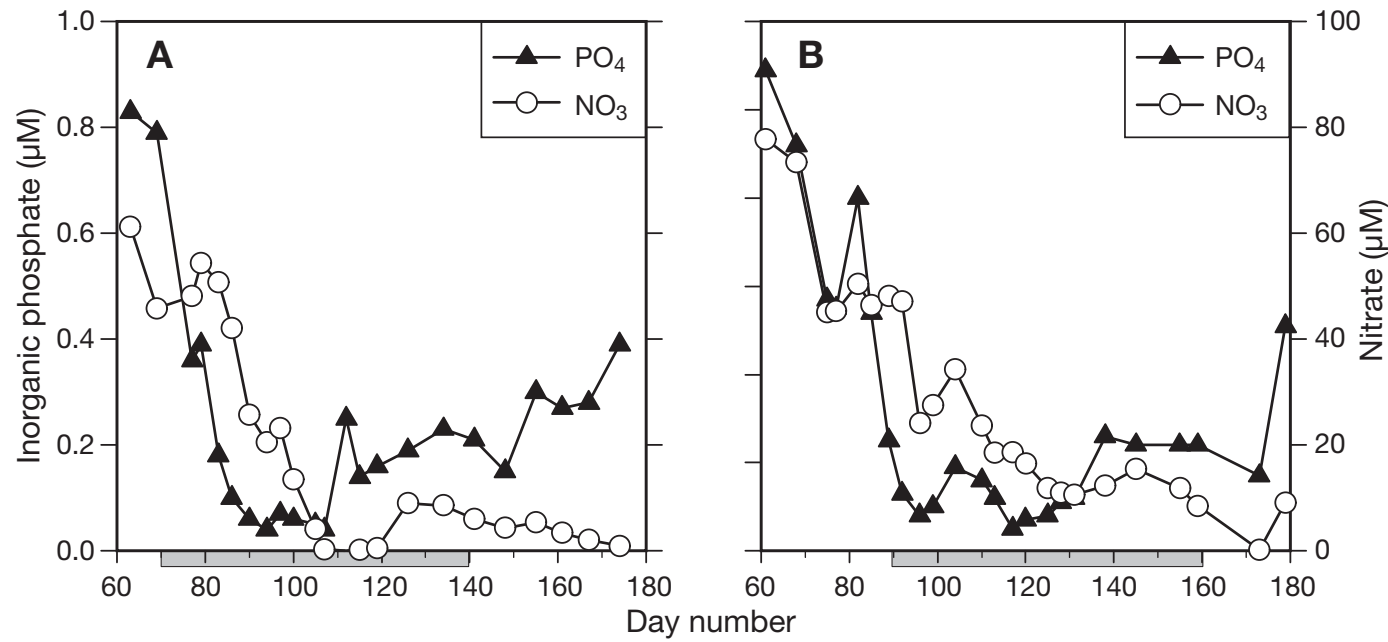

Fig. 4. Concentrations of dissolved inorganic phosphate and nitrate during spring in (A) 2003 and (B) 2004. Gray bars under $x$-axis indicate duration of Phaeocystis globosa bloom

The TEP concentration in 2004 (Fig. 5) increased steadily during the sampling period to a maximum of $1033 \mu \mathrm{g}$ equiv. GX $\mathrm{l}^{-1}$ on Day 128, after which it declined to a level comparable to the start of the sampling period (164 $\mu \mathrm{g}$ equiv. GX $\mathrm{l}^{-1}$ on Day 160).

\section{Phaeocystis globosa bloom dynamics}

The bloom of prymnesiophytes represented up to 70 and $40 \%$ of the total phytoplankton chlorophyll in 2003 and 2004, respectively (Fig. 6A,C). Phaeocystis globosa was likely the dominant prymnesiophyte during the experimental period. The magnitude and the composition of the blooms differed between years. The bloom in 2003 occurred between Days 70 and 141, reached a

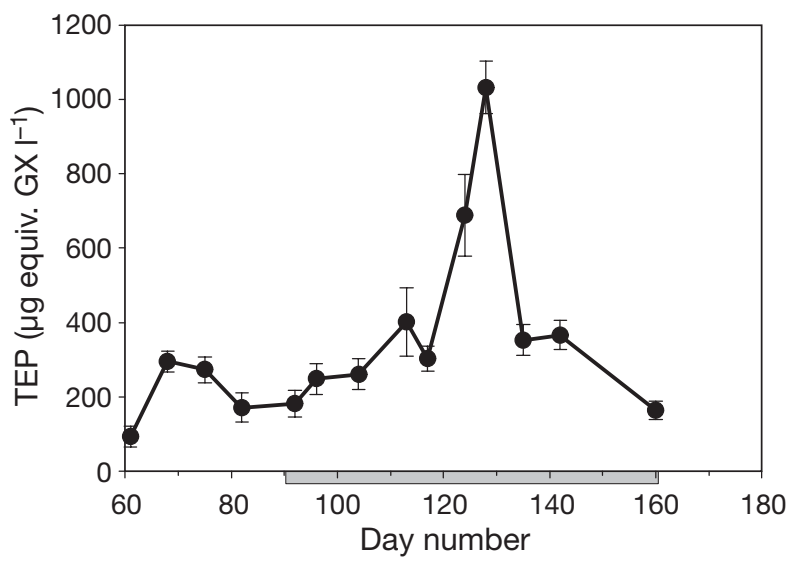

Fig. 5. Concentration of transparent exopolymeric particles (TEP) in $\mu \mathrm{g}$ equivalent gum xanthan (GX) $\mathrm{l}^{-1}$ during Phaeocystis globosa spring bloom in 2004 determined by semiquantitative method (Passow \& Alldredge 1995). Gray bars under $x$-axis indicate duration of $P$. globosa bloom in 2004 highest total cell abundance of $7.6 \times 10^{4}$ cells $\mathrm{ml}^{-1}$, and was generally dominated by the colonial cell morph (Fig. 6B). Single cells dominated over cells embedded in a colonial matrix only during peak events (e.g. Days 102 and 119). In 2004, a P. globosa bloom occurred between Days 92 and 159, reached only a 3 -fold lower cell abundance $\left(2.1 \times 10^{4}\right.$ cells ml-1 $)$ than in 2003, and was dominated by the single cell morphotype (Fig. 6D).

\section{Phaeocystis globosa-specific viruses}

Despite the low abundance of Phaeocystis globosa at the beginning of the sampling period, there was a substantial build-up of standing stock of putative PgVs in both 2003 and 2004 (Fig. 7). Putative PgV abundance increased concomitantly with the development of $P$. globosa biomass, largely corresponding to increased $P$. globosa single cells and/or reduced abundance of colonial P. globosa cells (Figs. 6B \& 7A). PgV reached abundances $>4 \times 10^{5} \mathrm{ml}^{-1}$ in both years.

The numerical increase in the infective PgVs (MPN method using Phaeocystis globosa Strain Pg-G) was delayed compared to the total putative PgV abundance as detected by flow cytometry (Fig. 7). Although not visible in Fig. 7, infective PgVs were recorded in each sample tested using $P$. globosa Strain Pg-G $\left(<1.8 \times 10^{3} \mathrm{ml}^{-1}\right.$ at Days 97, 105 and 113 in 2003; and $<25 \mathrm{ml}^{-1}$ from Days 60 to 120 in 2004). The maximum number of infective $\mathrm{PgV}$ was roughly comparable for 2003 and 2004 with 1.5 to $1.8 \times 10^{4}$ infective $\mathrm{PgV} \mathrm{ml}{ }^{-1}$ on Days 133 and 145, respectively. In both years, the infective $\mathrm{PgV}$ accounted for a maximum of $5 \%$ of the total putative $\mathrm{PgV}$ population. 

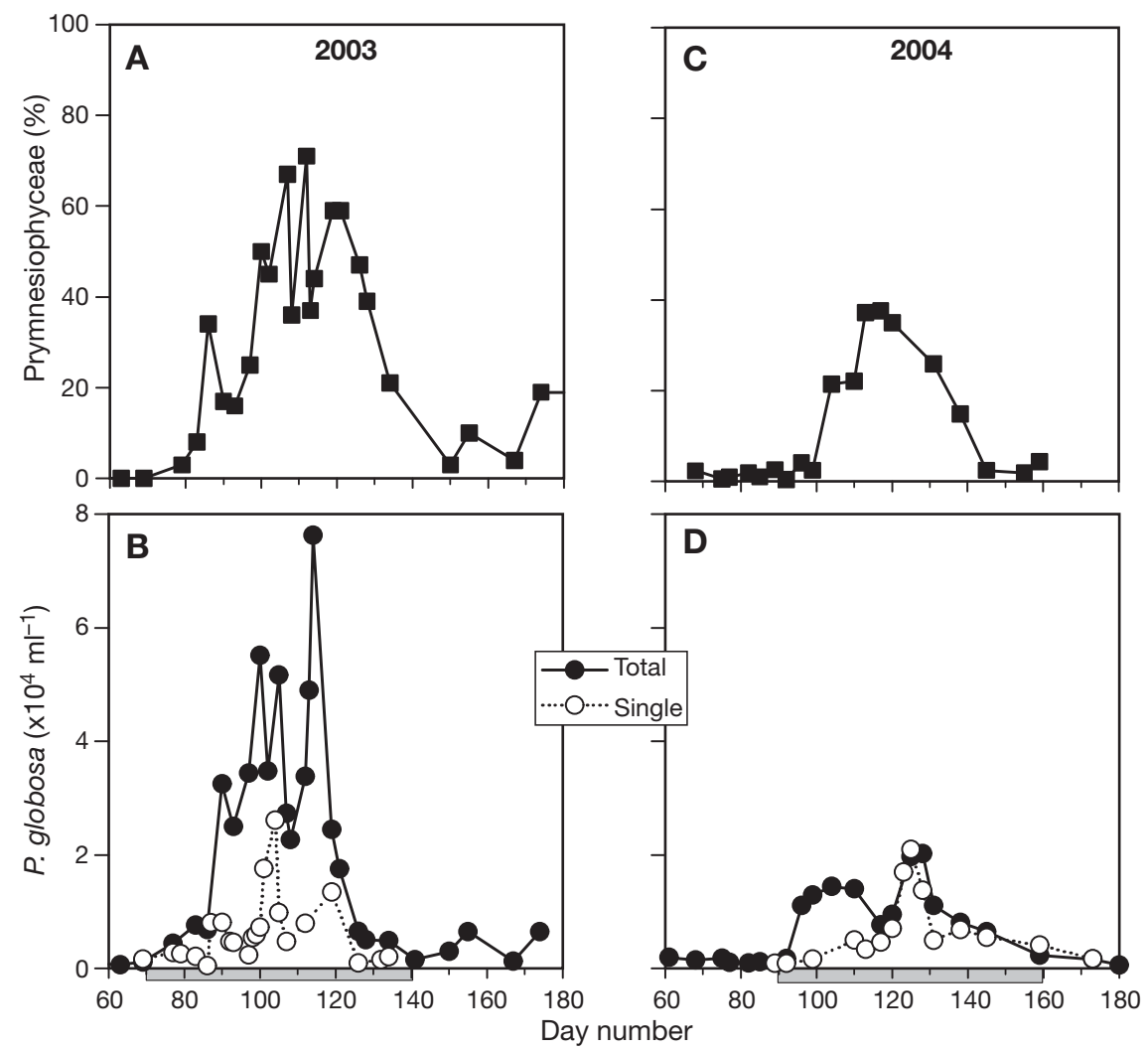

Fig. 6. Phaeocystis globosa. Bloom dynamics during spring 2003 and 2004. (A,C) Relative contribution of Prymnesiophyceae to total phytoplankton community based on pigment:chl a ratio (Prymnesiophyceae were mostly, if not only, represented by $P$. globosa during the sampling periods). (B,D) Abundance of single P. globosa cells and total cells (single plus colonial). Gray bars under $x$-axis indicate duration of P. globosa bloom

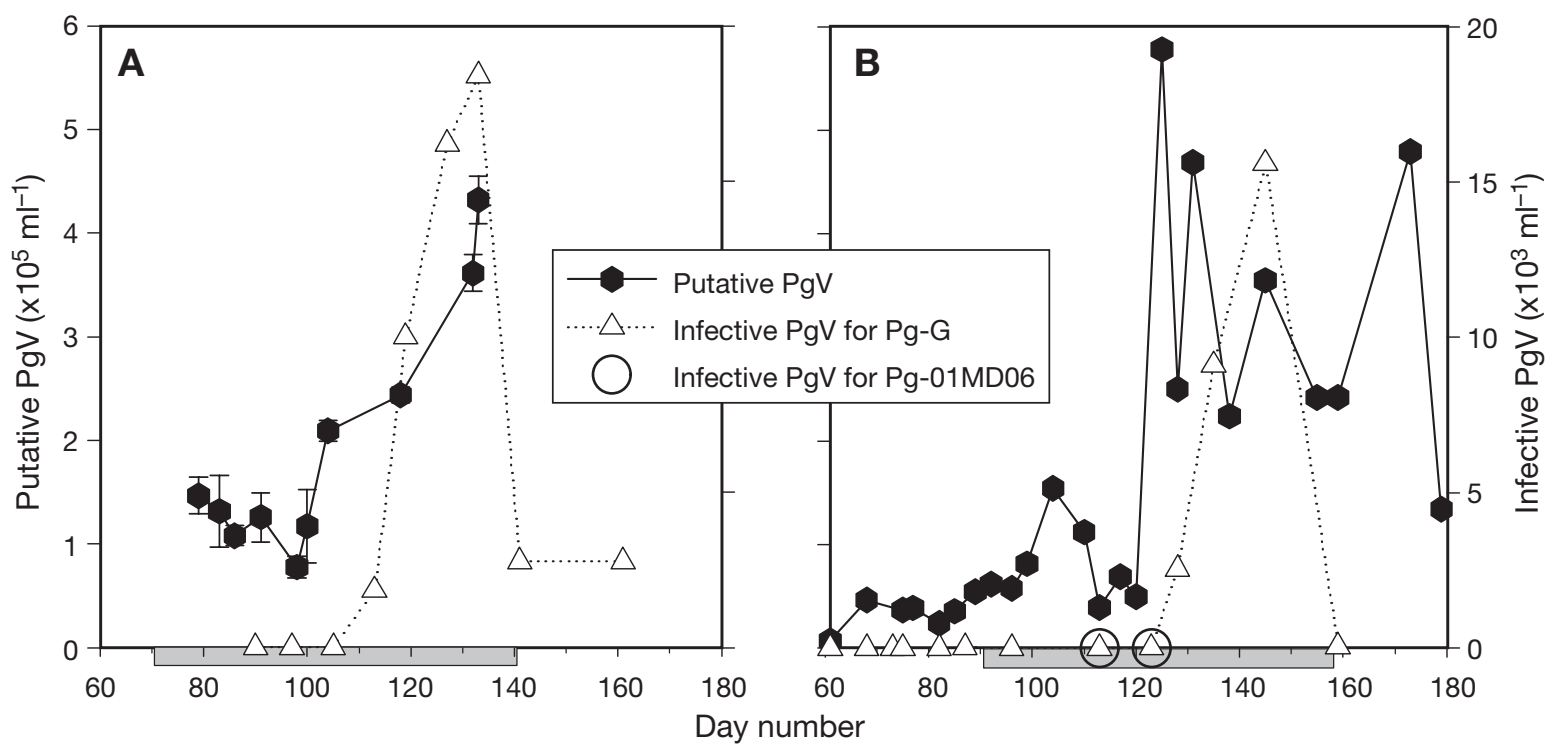

Fig. 7. Abundance of putative viruses infecting Phaeocystis globosa (Putative PgV) and infective PgV in (A) 2003 and (B) 2004. Total PgV was obtained using flow cytometry, whereas abundance of infective PgV resulted from end-point dilution (MPN) using P. globosa Strain Pg-G $(\Delta)$ with a broad sensitivity to PgV and Strain Pg-01MD06 with a narrow sensitivity to PgV (O). Only positive scores of virally induced cell lysis of $P$. globosa are presented. Gray bars under $X$-axis indicate the duration of $P$. globosa bloom 
In a previous study, Phaeocystis globosa Strain Pg-01MD06 was found to be specifically infected by only certain $\mathrm{PgV}$ isolates in culture (PgV Group II, Baudoux \& Brussaard 2005). Therefore, this P. globosa strain was also assayed during 2004 to determine whether different PgVs coexisted in the field. Cell lysis of the host due to viral infection was recorded for Days 113 and 123 (Fig. 7B).

\section{Viral lysis and grazing}

The rates of viral lysis and grazing by microzooplankton of Phaeocystis globosa single cells were estimated over the course of the blooms (Fig. 8). Virally mediated mortality rates in 2003 were low $(0.01$ to $0.03 \mathrm{~d}^{-1}$ ) until the collapse of $P$. globosa single cells, when viral lysis was high (0.35 $\mathrm{d}^{-1}$ on Day 132, Fig. 8A). This enhanced viral lysis rate concurred with the highest concentrations of total putative PgV as well as infective PgVs (Figs. 7A \& 8A). In contrast to viral lysis, microzooplankton grazing of $P$. globosa single cells was an important source of mortality during the entire bloom of P. globosa (Fig. 8A). During the course of the bloom, viral lysis accounted for 5 to $57 \%$ of the total mortality, assuming no losses of $P$. globosa single cells due to sinking.

Viral lysis rates were higher over the course of the bloom in 2004 (Fig. 8B, with values of 0.29, 0.19 and $0.24 \mathrm{~d}^{-1}$ on Days 123, 127 and 135, respectively) than in 2003, when viral lysis only increased at the end of the bloom $\left(0.35 \mathrm{~d}^{-1}\right.$ on Day 132). These high Phaeocystis globosa-specific viral lysis rates also coincided with

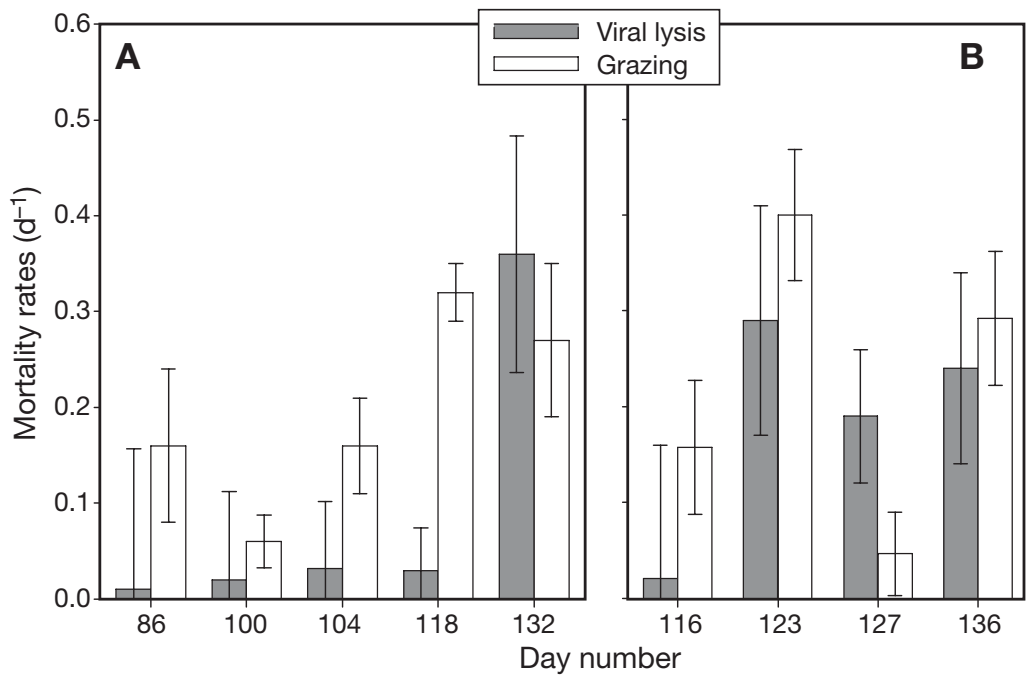

Fig. 8. Phaeocystis globosa. Viral lysis $\left(\mathrm{d}^{-1}\right)$ and microzooplankton grazing rates $\left(\mathrm{d}^{-1}\right)$ of single cells during different stages of $P$. globosa bloom in (A) 2003 and (B) 2004

increased abundances in total putative and infective PgV. Microzooplankton grazing in 2004 was another important loss factor for $P$. globosa single cells, with rates ranging between 0.05 and $0.40 \mathrm{~d}^{-1}$. Viral lysis represented 44,66 and $45 \%$ of total losses on Days 123 , 127 and 135, respectively.

The total Phaeocystis globosa-specific cell lysis varied during the course of the bloom in both years (Fig. 9). In 2003, total P. globosa cell lysis rates were $<0.1 \mathrm{~d}^{-1}$ until Day 121 and increased concomitantly with the collapse of the total $P$. globosa cell abundance $\left(0.2 \mathrm{~d}^{-1}\right.$ at Day 132). In 2004, total P. globosa cell lysis rates increased earlier (from Day 110). In both years, total cell lysis rates reached maximum rates of about $0.2 \mathrm{~d}^{-1}$.

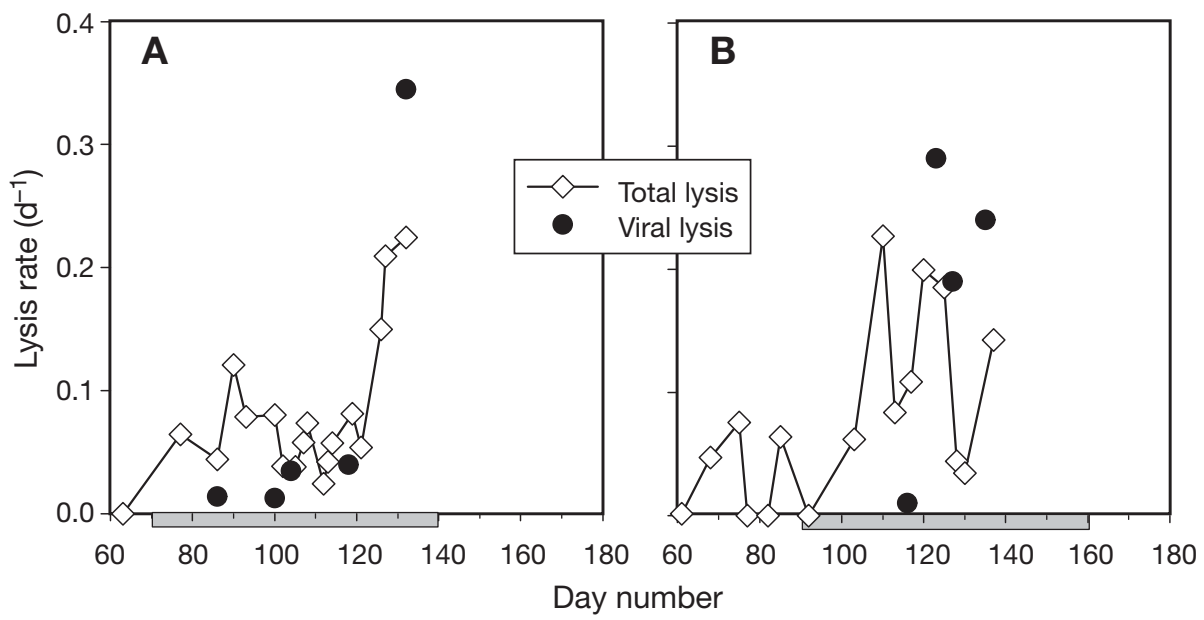

Fig. 9. Phaeocystis globosa. Daily viral lysis and total cell lysis rates during spring bloom in (A) 2003 and (B) 2004 . Gray bars under $\mathrm{X}$-axis indicate duration of $P$. globosa bloom 


\section{DISCUSSION}

The present study revealed that, next to grazing, virally mediated mortality was a major source of loss for Phaeocystis globosa cells during 2 consecutive spring blooms (in 2003 and 2004). Incidentally, viral lysis rates recorded during the blooms were higher than the microzooplankton grazing rates upon P. globosa cells. To our knowledge, this study is the first direct assessment of viral lysis rates in P. globosa under natural conditions. A recent study indicated that viruses can cause significant mortality of $P$. globosa cells, but the experiment was conducted under controlled conditions in mesocosms and estimates were based on virus production and assumed burst size (Brussaard et al. 2005a).

The Landry and Hassett dilution method (Landry \& Hassett 1982) was originally developed for the measurement of microzooplankton grazing and is now routinely applied in a broad range of aquatic environments (Landry \& Calbet 2004). Recently, an extended version of the dilution method was successfully developed to specifically estimate viral lysis of the picophytoplankter Micromonas pusilla (Evans et al. 2003). In the present study, the suitability of the method was demonstrated for Phaeocystis spp. using a cultured $P$. globosa host and virus model system. This test experiment validated the 2 critical assumptions of the original dilution method: (1) that phytoplankton growth rate is independent of the dilution factor, and (2) losses are proportional to the dilution effect on the abundance of the predators (Landry \& Hassett 1982, Landry et al. 1995). The viral lysis rate $\left(1.3 \mathrm{~d}^{-1}\right)$ obtained using this assay was comparable to that in an independent 1-step lytic cycle experiment $\left(1.4 \mathrm{~d}^{-1}\right)$. In order to estimate the number of $P$. globosa cells that underwent cell lysis during a $24 \mathrm{~h}$ period, the $\mathrm{PgV}$ produced in the non-diluted samples during the $24 \mathrm{~h}$ incubation were divided by a theoretical burst size of 100 to $300 \mathrm{PgV}$ produced per infected host cell (Baudoux \& Brussaard 2005). These values compared very well with those obtained by multiplying the cell abundance at the start of the incubation by the determined viral lysis rate, assuming no growth of the infected algal cells.

This assay exclusively detects viral lysis of newly infected algal hosts within the $24 \mathrm{~h}$ of incubation. This incubation period is essential to encompass the entire cellular diel cycle of phytoplankton that have synchronized cell cycles. The lytic nature of all known PgVs, as well as the 14 to $16 \mathrm{~h}$ required for Phaeocystis globosa to undergo cell lysis (Baudoux \& Brussaard 2005), favor the detection of $P$. globosa viral lysis using this dilution approach. However, the time between successful viral infection of a $P$. globosa cell and its subsequent lysis is critical, since late infection during the incubation period (later than $10 \mathrm{~h}$ ) will no longer result in cell lysis within the duration of the incubation. The potential impact of viruses on the P. globosa population is, therefore, likely to be underestimated. The lysis of P. globosa cells occurs 0 to $4 \mathrm{~h}$ after the first release of viral progeny of $\mathrm{PgV}$ (latent period of 10 to $16 \mathrm{~h}$, Baudoux \& Brussaard 2005). Thereby, a second round of infection by the newly produced viruses during the incubation period should not affect the viral lysis rates, since these newly infected host cells will not undergo lysis within the $24 \mathrm{~h}$ incubation.

Viral lysis rates were compared with the Phaeocystis globosa total cell lysis rates, which also included lysis due to causes other than viral infection (e.g. environmental stress). This comparison revealed that virally induced mortality was the most important cause of lysis and thereby supports the findings of P. globosa studies conducted in mesocosms (Brussaard et al. 2005a). Differences between total cell lysis and viral lysis rates of $P$. globosa likely represent other forms of cell lysis, e.g. automortality of the colonial cells from nutrient depletion (Ruardij et al. 2005). Deviations due to the use of 2 different parameters to estimate viral lysis and total cell lysis can, of course, not be excluded. Viral lysis was determined from the difference in $P$. globosa cell abundance over $24 \mathrm{~h}$ incubation using flow cytometry, whereas total cell lysis was estimated from the ratio of DEA to PEA. It may also be possible that the physiological status of cells influences the cellular esterase activity and thus the total lysis rates. Reduced percentages of dying cells were recorded for virally infected $P$. pouchetii cells in the early stationary growth phase upon staining with Calcein-AM, a fluorescent dye revealing intracellular esterase activity (Brussaard et al. 2001). We speculate that the lower total cell lysis rates compared to viral lysis rates at the end of the blooms might have been influenced by such methodological variations.

The composition and magnitude of the Phaeocystis globosa blooms differed for 2003 and 2004. The lower biomass of P. globosa colonies in 2003 and 2004 was likely to have been due to the lower standing stock of inorganic phosphate in 2004, which was half the concentration of that in 2003. One possible reason could be that silicate became growth-limiting later in 2004 than in 2003 (Day 92 in 2004, Day 83 in 2003). Thus, dominance of diatoms was prolonged and subsequently the concentration of phosphate was reduced when $P$. globosa biomass finally developed (Jahnke 1989, Egge \& Aksnes 1992). Another reason might be that the reduced mean water irradiance during the bloom period in 2004 (due to substantial cloud cover), limited colony formation (Peperzak 1993) and thus lowered P. globosa biomass. 
Virally induced mortality of Phaeocystis globosa cells as well as $\mathrm{PgV}$ abundance increased concomitantly with the development of the bloom, as was to be expected, since increasing host abundance enhances the rate of successful viral infection. Despite the higher total cell abundance of $P$. globosa in 2003, the maximal abundance of $\mathrm{PgV}$ was comparable in both years. It is suggested that $P$. globosa cells that are embedded inside a colonial matrix are protected against viral infection (Brussaard et al. 2005a, Ruardij et al. 2005). Interestingly, our results show that the abundance of colonial cells was higher in 2003 than in 2004 but that the abundance of single cells was comparable. This suggests that $\mathrm{PgV}$ was mainly produced by P. globosa single cells and thus corroborates the observations that colonies provide protection from viral infection. Hence, the morphotype composition of a P. globosa bloom is an important factor underlying the effect of viral infection on P. globosa.

When colonies disintegrate after experiencing nutrient depletion or light deprivation (Veldhuis et al. 1986, Peperzak 1993), cells are released into the surrounding waters and become readily infected (Brussaard et al. 2005a, Ruardij et al. 2005). In 2003, nitrate depletion (from Days 107 to 120 ) was most likely responsible for the major collapse in the abundance of colonial cells after Day 115, thus increasing the effect of viral lysis $\left(0.35 \mathrm{~d}^{-1}\right.$ at the end of the bloom $)$. Although the cause of colonial disintegration in 2004 is less obvious, the decline in colony abundance led to an increase in single cell abundance and enhanced viral lysis $\left(0.29 \mathrm{~d}^{-1}\right.$ on Day 123).

The difference in colony abundance between the 2 years is also likely to have influenced the dynamics of TEP, which are produced in high concentrations during colony disruption (Mari et al. 2005). TEP formation has recently been acknowledged as a major inhibitor of viral infection (Brussaard et al. 2005b, Ruardij et al. 2005). Viruses, like other microorganisms, tend to passively adsorb to TEP and therefore are not available to infect algal cells. In 2004, the period with the highest TEP concentration indeed coincided with a low abundance of infective $\mathrm{PgV}$ and reduced viral lysis rates. Interestingly, the disintegration of TEP concurred with an enhanced abundance of infective PgV. The concentrations of TEP recorded for 2004 were lower than those reported during a Phaeocystis globosa bloom with higher colonial cell abundance (100-1000 compared to $100-2000 \mu \mathrm{g}$ equiv. GX $\mathrm{l}^{-1}$; Mari et al. 2005). Thus, the higher abundance of colonies in 2003 induced, in all likelihood, a higher release of TEP and subsequently an enhanced effect of TEP on the fraction of $\mathrm{PgV}$ still infective, which in turn resulted in reduced viral lysis rates. Therefore it can be said that colonies play an ambiguous role, acting as a potential viral lysis inhibitor with TEP production but also as an enhancing agent of virally induced mortality as they constitute a potential reservoir of single cells.

The results of the present study also suggest regulation of viral infection on a finer scale, as the results from the end-point dilution assay (MPN) suggest the co-existence of different PgVs. The PgV population infecting Pg-01MD06 appeared and disappeared within $2 \mathrm{wk}$, implying that the $\mathrm{PgV}$ population in the field is diverse and dynamic. This has also been proposed by other authors for different algal viruses (Tarutani et al. 2000, Schroeder et al. 2003). The reason why this PgV population is not maintained in the water column is not clear. Possible reasons may be the removal of the specific host from the water column or a loss of infectivity of this specific viral population, but this needs further investigation.

In summary, this study has shown that viral lysis and grazing by microzooplankton are both major controlling agents of Phaeocystis globosa single cells, although the relative significance of each of these factors can vary during the course of the bloom and between years. The application of the dilution method based on cell counts in combination with total algal cell lysis rates and abundance of infective algal viruses provides essential insight into the quantitative significance of viral lysis compared to other loss factors. The present study has also provided insight into the ecological role of viral infection in relation to host population regulation and some of the mechanisms controlling successful infection.

Acknowledgements. We thank G. van Noort and C. Chenard for technical assistance, $\mathrm{H}$. Witte for statistical advice and T. Compton and C. Robertson for editing this manuscript. Thanks to L. Peperzak for sharing data and to the anonymous reviewers for their suggestions on the manuscript. Special thanks to B. Kuipers for general discussion, and to the editor for valuable comments on the manuscript. This work was supported by the Research Council for Earth and Life Sciences (ALW) with financial aid from the Netherlands Organization for Scientific Research (NWO).

\section{LITERATURE CITED}

Agusti S, Satta MP, Mura MP, Benavent E (1998) Dissolved esterase activity as a tracer of phytoplankton lysis: evidence of high phytoplankton lysis rates in the northwestern Mediterranean. Limnol Oceanogr 43:1836-1849

Baudoux AC, Brussaard CPD (2005) Characterization of different viruses infecting the marine harmful algal bloom species Phaeocystis globosa. Virology 341:80-90

Bratbak G, Egge JK, Heldal M (1993) Viral mortality of the marine alga Emiliania huxleyi (Haptophyceae) and termination of algal bloom. Mar Ecol Prog Ser 93:39-48

Brussaard CPD (2004a) Optimization of procedures for counting viruses by flow cytometry. Appl Environ Microbiol 70: 1506-1513

Brussaard CPD (2004b) Viral control of phytoplankton popu- 
lations - a review. J Eukaryot Microbiol 51:125-138

Brussaard CPD, Riegman R, Noordeloos AAM, Cadee GC and 5 others (1995) Effects of grazing, sedimentation and phytoplankton cell lysis on the structure of a coastal pelagic food web. Mar Ecol Prog Ser 123:259-271

Brussaard CPD, Gast GJ, Van Duyl FC, Riegman R (1996a) Impact of phytoplankton bloom magnitude on a pelagic microbial food web. Mar Ecol Prog Ser 144:211-221

Brussaard CPD, Kempers RS, Kop AJ, Riegman R, Heldal M (1996b) Virus-like particles in a summer bloom of Emiliania huxleyii in the North Sea. Aquat Microb Ecol 10:105-113

Brussaard CPD, Marie D, Thyrhaug R, Bratbak G (2001) Flow cytometric analysis of phytoplankton viability following viral infection. Aquat Microb Ecol 26:157-166

Brussaard CPD, Short SM, Frederickson CM, Suttle CA (2004) Isolation and phylogenetic analysis of novel viruses infecting the phytoplankton Phaeocystis globosa (Prymnesiophyceae). Appl Environ Microbiol 70:3700-3705

Brussaard CPD, Kuipers B, Veldhuis MJW (2005a) A mesocosm study of Phaeocystis globosa population dynamics. I. Regulatory role of viruses in bloom control. Harmful Algae 4:859-874

Brussaard CPD, Mari X, Van Bleijswijk JDL, Veldhuis MJW (2005b) A mesocosm study of Phaeocystis globosa (Prymnesiophyceae) population dynamics. II. Significance for the microbial community. Harmful Algae 4:875-893

Cottrell MT, Suttle CA (1991) Wide-spread occurrence and clonal variation in viruses which cause lysis of a cosmopolitan eukaryotic marine phytoplankter, Micromonas pusilla. Mar Ecol Prog Ser 78:1-9

Egge JK, Aksnes DL (1992) Silicate as regulating nutrient in phytoplankton competition. Mar Ecol Prog Ser 83:281-289

Evans C, Archer SD, Jacquet S, Wilson WH (2003) Direct estimates of the contribution of viral lysis and microzooplankton grazing to the decline of a Micromonas spp. population. Aquat Microb Ecol 30:207-219

Grasshoff K (1983) Determination of nutrients. In: Grasshoff K, Ehrhardt M, Kremling M (eds) Methods of seawater analysis. Verlag Chemie, Weinheim, p 143-150

Guillard RRL (1975) Culture of phytoplankton for feeding marine invertebrates. In: Chanley $\mathrm{MH}$ (ed) Culture of marine invertebrate animals. Plenum Press, New York, p 29-60

Harrison PJ, Waters RE, Taylor FJR (1980) A broad spectrum artificial seawater medium for coastal and open ocean phytoplankton. J Phycol 16:28-35

Helder W, De Vries R (1979) An automatic phenol-hypochlorite method for the determination of ammonia in sea- and brackish waters. Neth J Sea Res 13:154-160

Hurley MA, Roscoe ME (1983) Automated statistical analysis of microbial enumeration by dilution series. J Appl Bacteriol 55:159-164

Jahnke J (1989) The light and temperature-dependence of growth rate and elemental composition of Phaeocystis globosa Scherffel and Phaeocystis pouchetii (Har) Lagerh in batch cultures. Neth J Sea Res 23:15-21

Lancelot C, Billen G (1984) Activity of heterotrophic bacteria and its coupling to primary production during the spring phytoplankton bloom in the southern bight of the North Sea. Limnol Oceanogr 29:721-730

Landry MR, Calbet A (2004) Microzooplankton production in the oceans. ICES J Mar Sci 61:501-507

Landry MR, Hassett RP (1982) Estimating the grazing impact of marine microzooplankton. Mar Biol 67:283-288

Landry MR, Kirshtein J, Constantinou J (1995) A refined dilu- tion technique for measuring the community grazing impact of microzooplankton, with experimental tests in the central equatorial Pacific. Mar Ecol Prog Ser 120:53-63

Mackey MD, Mackey DJ, Higgins HW, Wright SW (1996) CHEMTAX - a program for estimating class abundances from chemical markers: application to HPLC measurements of phytoplankton. Mar Ecol Prog Ser 144:265-283

Mari X, Rassoulzadegan F, Brussaard CPD, Wassmann P (2005) Dynamics of transparent exopolymeric particles (TEP) production by Phaeocystis globosa under N- or P-limitation: a controlling factor of the retention/export balance. Harmful Algae 4:895-914

Murphy J, Riley JP (1962) A modified single solution method for the determination of phosphate in natural waters. Anal Chim Acta 27:31-36

Passow U, Alldredge AL (1995) A dye-binding assay for the spectrophotometric measurement of transparent exopolymer particles (TEP). Limnol Oceanogr 40:1326-1335

Peperzak L (1993) Daily irradiance governs growth-rate and colony formation of Phaeocystis (Prymnesiophyceae). J Plankton Res 15:809-821

Riegman R, Kraay GW (2001) Phytoplankton community structure derived from HPLC analysis of pigments in the Faroe-Shetland Channel during summer 1999: the distribution of taxonomic groups in relation to physical/chemical conditions in the photic zone. J Plankton Res 23:191-205

Riegman R, van Bleijswijk JDL, Brussaard CPD (2002) The use of dissolved esterase activity as a tracer of phytoplankton lysis - comment. Limnol Oceanogr 47:916-920

Ruardij P, Veldhuis MJW, Brussaard CPD (2005) Modeling the bloom dynamics of the polymorphic phytoplankter Phaeocystis globosa: impact of grazers and viruses. Harmful Algae 4:941-963

Schroeder DC, Oke J, Hall M, Malin G, Wilson WH (2003) Virus succession observed during an Emiliania huxleyii bloom. Appl Environ Microbiol 69:2484-2490

Stefels J, Van Boekel WHM (1993) Production of DMS from dissolved DMSP in axenic cultures of the marine phytoplankton species Phaeocystis sp. Mar Ecol Prog Ser 97: 11-18

Strickland JDH, Parsons TR (1968) A practical handbook of seawater analysis. Bull Fish Res Board Can 167:1-311

Suttle CA (1993) Enumeration and isolation of viruses. In: Kemp PF, Sherr BF, Sherr EF, Cole JJ (eds) Current methods in aquatic microbial ecology. Lewis Publishers, Boca Raton, FL, p 121-134

Suttle CA, Chan AM, Cottrel MT (1991) Use of ultrafiltration to isolate viruses from seawater which are pathogens of marine plankton. Appl Environ Microbiol 57:721-726

Tarutani K, Nagasaki K, Yamaguchi M (2000) Viral impacts on total abundance and clonal composition of the harmful bloom-forming phytoplankton Heterosigma akashiwo. Appl Environ Microbiol 66:4916-4920

Tomaru Y, Tarutani K, Yamaguchi M, Nagasaki K (2004) Quantitative and qualitative impacts of viral infection on a Heterosigma akashiwo (Raphidophyceae) bloom in Hiroshima Bay, Japan. Aquat Microb Ecol 34:227-238

Van Boekel WHM, Hansen FC, Riegman R, Bak RPM (1992) Lysis induced decline of a Phaeocystis spring bloom and coupling with the microbial food web. Mar Ecol Prog Ser 81:269-276

Veldhuis MJW, Admiraal W, Colijn F (1986) Chemical and physiological-changes of phytoplankton during the spring bloom, dominated by Phaeocystis pouchetii (Haptophyceae) - observations in Dutch coastal waters of the North Sea. Neth J Sea Res 20:49-60

Submitted: January 24, 2006; Accepted: July 7, 2006

Proofs received from author(s): September 22, 2006 